\title{
Enzymatic peeling: first advance on the development of the flavor sensory profile of Navel oranges
}

\author{
Pelado enzimático: primer avance en el desarrollo del perfil \\ sensorial de sabor de cultivares de naranjas Navel \\ Victoria Pieroni ${ }^{1,2 *}$, Fernanda Gugole Ottaviano ${ }^{1,3}$, Julieta Gabilondo ${ }^{4}$, \\ Claudio Budde ${ }^{4}$, Silvina Andres ${ }^{5}$, Lorena Garitta ${ }^{1,2}$
}

\begin{abstract}
Enzymatic peeling is one of the methods used to obtain minimally processed citrus fruit. The present work has studied the effect of enzymatic peeling produced on the flavor sensory profile of different cultivars of navel oranges. A trained panel conducted a descriptive analysis. The following flavor descriptors were defined and evaluated: bitter, sweet, acid, orange, and fermented. The enzymatic treatment has influenced the three orange cultivars studied in different manners. In Navelina cultivar, this treatment affected negatively, intensifying bitterness and fermented flavor, so it would not be a recommended cultivar to be minimally processed. Lane late cultivar was affected by enzymatic treatment in sweetness and orange flavor descriptors, decreasing their intensity. In the Parent cultivar, the peeling treatment has not affected the flavor of oranges as this cultivar of oranges remains as one of the sweetest and most orange-flavored ones.
\end{abstract}

Keywords: Cultivars, fruit, sensory analysis, minimally processed.

\section{RESUMEN}

El pelado enzimático es uno de los métodos utilizados para obtener cítricos mínimamente procesados. En este trabajo se estudió el efecto del pelado enzimático sobre el perfil sensorial de sabor de diferentes cultivares de naranjas Navel. Se realizó un análisis descriptivo mediante un panel entrenado. Se definieron y evaluaron los siguientes descriptores del sabor: amargo, dulce, acido, naranja y fermentado. El tratamiento enzimático influenció de diferente manera en el perfil de los tres cultivares de naranja estudiado. En el cultivar Navelina, el tratamiento tuvo un efecto negativo, intensificando el sabor amargo y fermentado, por este motivo no sería un cultivar recomendado para tratar enzimáticamente. El cultivar Lane late fue afectado por el tratamiento enzimático en los descriptores dulce y sabor a naranja, disminuyendo su intensidad. En el cultivar Parent, el pelado enzimático no afectó el sabor de las naranjas y fue una de las más dulces y con más sabor a naranja.

Palabras claves: Cultivares, fruta, análisis sensorial, mínimamente procesado.

\section{Introduction}

Food habits have changed through the last decades. The current rhythm of life, mainly characterized by limited time to prepare balanced meals, has increased the need for natural, fresh, healthy and ready-to-eat vegetable products (ArtésHernández et al., 2009). In response to this demand, minimally processed fruits and fresh production vegetables, also called 'ready-to-eat' or 'ready to use' products, have been developed. That are raw fruit and vegetables that have been washed, peeled,

1 Instituto Superior Experimental de Tecnología Alimentaria - Comisión de Investigaciones Científicas de la Provincia de Buenos Aires (ISETA-CIC). Buenos Aires, Argentina.

2 Consejo Nacional de Investigaciones Científicas y Técnicas (CONICET).Buenos Aires, Argentina.

3 Comisión de Investigaciones Científicas de la provincia de Buenos Aires (CICPBA).Buenos Aires, Argentina.

4 Estación Experimental Agropecuaria INTA San Pedro. Buenos Aires, Argentina.

5 Centro de Investigación y Desarrollo en Criotecnología de Alimentos (CIDCA), CONICET-CICPBA- Fac. Cs. Exactas UNLP. La Plata, Argentina.

* Corresponding author: victoria@desa.edu.ar

Fecha de Recepción: 5 de Abril, 2021.

Fecha de Aceptación: 27 de Junio, 2021. 
sliced, chopped or shredded into $100 \%$ usable product without further treatments (Parzanese, 2012; Gross et al., 2016). They are bagged or packaged and then distributed under refrigerated conditions into retail points to offer consumers higher nutritional-value and flavor, economic convenience, but still maintaining their freshness for longer time (De Corato, 2019) and with the advantage that they are easy to use for consumers (Parzanese, 2012). However, the quality of minimally processed fruits may vary quickly during storage, mostly due to biological processes, such as respiration, ripening and senescence. These fruit processes may cause significant changes in quality attributes such as texture, color and flavor (Karacay and Ayhan, 2010).

Some fruits like oranges have specific physiological (non-climacteric), morphological (structure into wedges) characteristics and are chilling-tolerant, so as to make them suitable for minimally processed food/requirements (Plaza et al., 2011). The relatively low respiration rate and the high acidity of citrus fruit should make oranges a stable product. Ready-to-eat oranges are relevant since the fresh market is often limited and due to the inconvenience of peeling, especially due to the release of essential oils (Groppo, et al., 2009), and the smell left by the essential oils and the juice spilled on the consumers' hands (Arruda Jacomino et al., 2009). Despite that need, readyto-eat oranges are still difficult to find in stores (Pinnavaia, et al., 2007). Enzymatic peeling is one of the methods used to obtain minimally processed citrus fruits that generate less pollution than traditional processes. The enzyme pectinase or cellulase digested the albedo, facilitating peel removal (Pretel et al., 1997, Ismail et al., 2005). This technology has been optimized and adapted to the different species and factors that may influence the quality of the final product, such as the adherence of the skin to the fruit, the segments between them and the thickness of the skin, among others (Pretel et al., 2008).

In Argentina, oranges are one of the most popular and consumed fruits. In addition, it is a citrus with one of the largest areas implanted due to its plasticity, with commercial crops existing in the coastal and northwest areas of the country (Ernst, 2020). However, as it has been previously mentioned, one of the factors that limits the consumption of this fresh fruit is peeling, due to the inconvenience that this operation causes to consumers.
Navel orange is one of the popular fruits among many sweet orange cultivars, because of its special flavor and high phytochemical content (Xiang et al., 2019). It is primarily used in the preparation of beverages, sweets, dairy products and cakes because of its aroma and flavor (Bourgou et al., 2012). Although enzymatic peeling is not a new technique, its applicability with navel oranges cultivars, spread in our region such as Navelina, Lane late and Parent cultivars, has not yet been studied.

Currently, the need to complement technological aspects with sensory aspects for developing new food products is widely accepted. From this viewpoint, the demands of today's fruit and vegetable consumers are increasingly oriented towards qualitative aspects, rather than quantitative ones (Mondino and Ferratto, 2006).

Descriptive Analysis is one of the most used methods to characterize sensory attributes of products, providing a complete description of important sensory properties. (Porto Cardoso and Bolini, 2008). Descriptive sensory analysis with trained panel is an appropriate approach to provide a complete and objective description of sensory perception in qualitative and quantitative terms (Murray, 2001). Sensory judges then quantify these product aspects in order to facilitate description of the perceived product attributes. Several variations and refinements in descriptive analysis techniques have been forthcoming. The Flavor Profile Method is a consensus technique, vocabulary development and qualification sessions, which take place during group discussions, with panel members considering aspects of the overall flavor and detectable flavor components of food (Murray, 2001).

Although there are studies that evaluate the sensory effect of peeling (Plaza et al., 2011), information on sensory profiles of enzymatically peeled oranges are scarce.

This work has been aimed to study the effect of enzymatic peeling produced on the flavor's profile of different cultivars of navel oranges.

\section{Material and methods}

\section{Fruit material}

Three navel oranges (Citrus $\times$ sinensis (L.) Osbeck), cultivar Navelina, Parent and Lane late were obtained from the Central Market of Buenos Aires, in July 2018. The ratio of the three cultivars 
was similar (8.55, 9.29 and 7.81 for Navelina, Parent and Lane late, respectively). All oranges were kept on camera at $0{ }^{\circ} \mathrm{C}$ until processing. Each orange cultivar was subjected to two peeling treatments: manual and enzymatic. Before it, the orange was washed with water containing $2 \%$ tween 20 , for two minutes and then disinfected for two minutes more, with 200 ppm chlorinated water.

The fruit was sensory tested in a period of 10 days span to limit changes to the fruit.

\section{Treatments (types of Peeling)}

Manual treatment (M): Control samples of each cultivar were obtained by manual peeling using a metal knife. First, cutting up the ends of the orange and then peeled from top to bottom, removing the flavedo.

Enzymatic treatment (E): Five cuts longitudinal were made to the flavedo of each orange from top to bottom poles to permit the infusion of treatment solutions into the albedo and place in a glass desiccator.

The enzymatic solution ( $1 \% \mathrm{v} / \mathrm{v})$ used consists in $2.5 \mathrm{~L}$ of demineralized water at $45^{\circ} \mathrm{C}$ with $25 \mathrm{~cm} 3$ of enzyme pectinase (Milar $H ®$ ) and chloride acid (pH:4.5). Oranges were infused by evacuating the chamber to $600 \mathrm{~mm} \mathrm{Hg}$ holding the vacuum for $2 \mathrm{~min}$. and then slowly releasing it over a 1-min interval. This operation has been repeated three times. When removing the oranges from the desiccator, they easily peeled under the tap water. The enzymatic solution was reused only once to avoid strange flavors, and to avoid decreasing pectinase activity (Pretel et al., 2007).

The two treatments were performed two days before starting the sensory test. Then the oranges were stored in refrigeration at $4 \pm 2{ }^{\circ} \mathrm{C}$, and the samples were placed at $20 \pm 2{ }^{\circ} \mathrm{C}, 30 \mathrm{~min}$. before starting each panel session.

\section{Descriptive analysis}

The sensory profile was carried out by a panel of 10 assessors who were selected and trained following the guidelines of ISO (2012). They all present a minimum of $100 \mathrm{~h}$ experience in discrimination and descriptive tests.

The samples were tested in a sensory laboratory equipped with individual booths, day-light type fluorescent lighting, air extractor and controlled temperature.
Assessors have evaluated only flavor, because enzymatic treatment mainly affects this attribute of the product, appearing unpleasant flavors, such as bitterness caused by limonene in citrus fruits (Pao and Petracek 1997).

All panelists have completed six training sessions before samples measurement. The first two sessions involved term generation based on the navel orange flavor, and references selection and then discussed in an open session (Rogers, 2017).

References were prepared to standardize the meaning of each descriptor. In the first training session, aqueous reference solutions for acid $(0.3 \mathrm{~g} / \mathrm{l})$, bitter $(0.3 \mathrm{~g} / \mathrm{l})$ and sweet taste $(10 \mathrm{~g} / \mathrm{l})$ were presented to assessors. As acid and bitter aqueous solution was perceived in low intensity regarding the samples evaluated, in the second session these references were presented with twice of the concentration. The sweet taste reference, on the other hand, has turned out to be of high intensity, for this reason, another reference was presented with a lower concentration, resulting in a solution of $6 \mathrm{~g} / \mathrm{l}$. For orange flavor reference, a manual juicer extractor with filters was used. Fresh juice without the pulp of orange cultivar Lane late was presented to the assessors. For fermented reference, a squeezed juice without pulp from cultivar Navelina has been prepared. In this case over-ripe oranges, which did not present fungi or yeasts, but that are discarded on the market, were used. The oranges that were used to prepare it were also been obtained from the Central Market of Buenos Aires.

The assessor assigned a value to each reference and then used them to evaluate the intensities of the samples in each descriptor considering a $0-10$ scale: acid (5.5), bitter (8), sweet (7), orange (7) and fermented (6).

Taking into consideration the inherent variability of the fruits, in each session, 5 oranges from the same treatment were randomly selected, and each evaluator was assigned 1 segment per sample. After training sessions, the assessors were submitted to monadic tests in individual booths, and the samples was coded with a three-digit number, in two repetitions. A sensory score sheet with $10 \mathrm{~cm}$ unstructured scale lines (0-10), each with anchored terms at both ends was used to indicate the intensity of each descriptor by placing a vertical line on the scale. In each measurement session, samples presentation was randomly made for each assessor. Water was provided to clean their palates in between samples. 


\section{Statistical analysis}

Two-way ANOVA was applied to each descriptor considering treatment, cultivar and interaction treatment*cultivar as fixed effects, and the assessors as a random effect. Means were compared using Fisher's least significant difference (LSD), at a 5\% significance level. Statistical analyses were performed using Genstat 19th edition (VSN International Ltd., Hempstead, United Kingdom).

\section{Results and discussion}

ANOVA showed differences between treatments in all descriptors. Samples with enzymatic peeling (E) have shown greater acid intensity, bitter and fermented flavor than the samples with manual peeling (M). Whereas samples with (M) treatment were distinguished due to a sweeter and orange taste
(Figure 1). The main effect cultivar also presented significant differences in all descriptors, except for orange taste. The cultivar Navelina has been considered the most bitter and fermented flavor, while the cultivar Lane late has been considered the most acidic and with cultivar Parent the sweetest (Figure 2).

In all descriptors, interaction treatment*cultivar was significant (Table 1). The most acidic sample was Navelina with $\mathrm{E}$ treatment finding differences with Navelina (M). Lane late (E) and Lane late (M) have also turned out to be samples that presented a high acid value, so it could be an intrinsic characteristic of the cultivar since the treatment has not apparently influenced that descriptor. The same happened with the Parent (E) and Parent (M) samples, but in this case, they were evaluated as less acidic.

In this work, the bitter taste was an outstanding feature only in Navelina (E), as this sample presented higher intensity, than the other evaluated

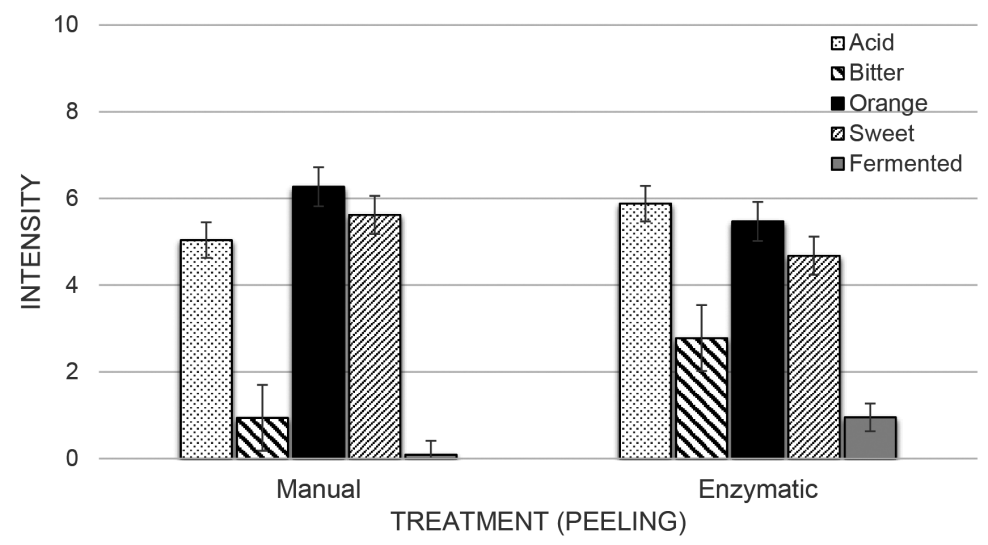

Figure 1. Intensity (mean) of flavor descriptors in oranges with enzymatic and manual peeled.

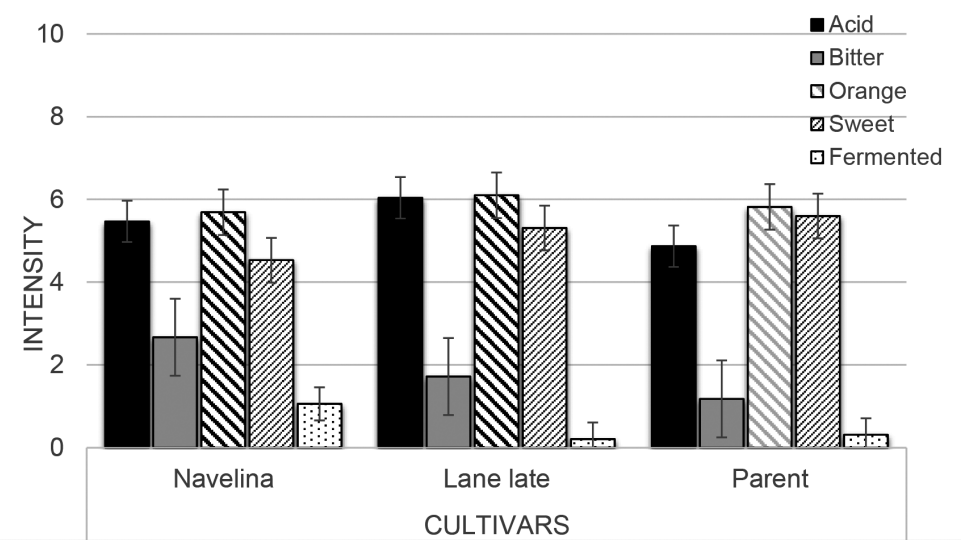

Figure 2. Intensity (mean) of flavor descriptors evaluated in three cultivars. 
Table 1. Intensity (mean) of flavor descriptors for treatment*cultivar

\begin{tabular}{|c|c|c|c|c|c|c|c|c|c|c|}
\hline \multicolumn{11}{|c|}{ Samples } \\
\hline & \multicolumn{2}{|c|}{ Acid } & \multicolumn{2}{|c|}{ Bitter } & \multicolumn{2}{|c|}{ Sweet } & \multicolumn{2}{|c|}{ Orange } & \multicolumn{2}{|c|}{ Fermented } \\
\hline Treatment/Cultivar & $\mathrm{E}$ & M & $\mathrm{E}$ & M & $\mathrm{E}$ & M & $\mathrm{E}$ & M & $\mathrm{E}$ & M \\
\hline Lane late & $6.24 b$ & $5.83 \mathrm{~b}$ & $2.19 b$ & $1.25 \mathrm{ab}$ & $4.63 b$ & $6.00 \mathrm{c}$ & $5.69 \mathrm{ab}$ & $6.50 \mathrm{c}$ & $0.25 \mathrm{a}$ & $0.17 \mathrm{a}$ \\
\hline Navelina & $6.33 b$ & $4.61 \mathrm{a}$ & $4.50 \mathrm{c}$ & $0.83 \mathrm{a}$ & $3.73 \mathrm{a}$ & $5.33 \mathrm{bc}$ & $5.06 \mathrm{a}$ & $6.33 b c$ & $2.11 b$ & $0.00 \mathrm{a}$ \\
\hline Parent & $5.07 \mathrm{a}$ & $4.67 \mathrm{a}$ & $1.64 \mathrm{ab}$ & $0.72 \mathrm{a}$ & $5.67 \mathrm{c}$ & $5.53 \mathrm{c}$ & $5.67 \mathrm{ab}$ & $5.97 \mathrm{bc}$ & $0.50 \mathrm{a}$ & $0.11 \mathrm{a}$ \\
\hline $\mathrm{LSD}^{\mathrm{a}}$ & \multicolumn{2}{|c|}{0.71} & \multicolumn{2}{|c|}{1.31} & \multicolumn{2}{|c|}{0.76} & \multicolumn{2}{|c|}{0.78} & \multicolumn{2}{|c|}{0.56} \\
\hline
\end{tabular}

References: E: Enzymatic peeled, M: manual peeled.

a Least significant difference (LSD) at a $5 \%$ significance level.

Note: different letters denote significant differences $(\mathrm{p}<0.05)$ for interaction treatment*cultivar.

samples (Table 1). Glycoside that is hydrolyzed imparting a strong bitter taste (Jackson and Looney, 2003). In addition, Pao and Petracek (1997) showed that increased membrane damage and juice leakage that is caused by cutting resulted in more rapid formation of limonine in comparison to the whole fruit that sustained membrane damage only during the peeling process. This difficulty could be a factor to consider when evaluating the bitterness present in the samples. However, a feature of the Lane late cultivar may be its low limonine content (Estación Experimental La Palma, 2020), so it could be possible that this may be the result of it not intensifying with the enzymatic treatment, or at least not causing a greater bitter taste perception.

In addition, the three samples with manual treatment presented the sweetest flavor and Parent (E). Whereas, Navelina (E) had the lowest values (Figure 2). Something similar happened with orange flavor, but in this case, the three samples with enzymatic treatment did not differ in intensity.

Although the fermented flavor was perceived in low intensity, some significant differences were found, being Navelina (E) the one with the highest intensity.

As is also observed in Table 1, the samples of Parent (M) and Parent (E) did not show significant differences in all the evaluated descriptors. We may then conclude that the peeling treatment did not affected the flavor in this cultivar. Pinnavaia et al. (2007) found similar results in cultivar Valencia. They compared fresh slices with those that were infused under vacuum with solutions of water, enzyme or citric acid along with a postcutting treatment in the form of a citric acid dip in order to obtain a desired effect on shelf life, microbial stability, and quality. No significant differences were found between the treatments, the author suggested that a trained panel could detect flavor changes more easily.

\section{Conclusion}

The descriptive test that has been conducted has allowed, in the first instance, the definition of the descriptors and their respective references to evaluate the flavor of three navel orange cultivars enzymatically peeled.

In addition, the flavor changes perceived by the panel in the different samples have been determined. The enzymatic treatment has influenced the three orange cultivars studied in different manners. In cultivar Navelina, this treatment has affected in a negative way, as it has intensified the bitterness and fermented flavor. In view of this, we may then conclude that it would not be recommended cultivar to be minimally processed. The Lane late cultivar has been affected by enzymatic treatment in sweet and orange descriptors by decreasing their intensity. In cultivar Parent peeling treatment has not affected the flavor of oranges and has been one of the sweetest and most orange-flavored.

There is no record of how enzymatic treatment affects these cultivars, so it is a first step to continue the research to know the influence of peeling treatment in the same cultivars and others to revalidate the results obtained in this study. In addition, it would be interesting to consider other variables, such as harvest time and changes over time.

\section{Acknowledgments}

We may want to give special thanks to the assessors for their valuable contribution to the study. 


\section{Literature cited}

Arruda, M.C.; Jacomino, A.P.; Pinheiro, A.L.; Iuamoto, M.Y. 2009. Orange Peeling Technologies. Recent Patents on Food, Nutrition \& Agriculture, 1: 216-220.

Artés-Hernández, F., Aguayo, E., Gómez, P.; Artés, F. 2009. Innovaciones tecnológicas para preservar la calidad. Productos vegetales mínimamente procesados o de la "cuarta gama". Horticultura Internacional, 69: 52-57.

Bourgou, S., Rahali, F.Z., Ourghemmi, I.; Saidani Tounsi, M. 2012. Changes of peel essential oil composition of four Tunisian citrus during fruit maturation. Scientific World Journal, 1-10. De Corato, U.

2019. Improving the shelf-life and quality of fresh and minimally-processed fruits and vegetables for a modern food industry: A comprehensive critical review from the traditional technologies into the most promising advancements. Critical Reviews in Food Science and Nutrition, 60(6): 940-975

Ernst, B.

2020. Naranjas en Argentina. Asociación de Ingenieros Agrónomos del Nordeste de Entre Ríos. Retrived from: https://www.aianer.com.ar/noticias/931_naranjas-enargentina.html. Accessed: 21/Sep/2020.

Estación Experimental La Palma.

Facultad de Ciencias Agronómicas y de los alimentos. Chile. Retrived from: http://eelapalma.pucv.cl/web/?portfolio=lanelate. Accessed: 15/Mar/2020.

Groppo, V.D., Spoto, M.H.F., Gallo, C.R.; Sarmento, S.B.S.

2009. Effect of calcium chloride and film of sodium alginate in the conservation of minimally processed "Pera" orange. Journal of Food Science and Technology, 29(1): 107-113.

Gross, K.C., Wang, C.Y.; Saltveit, M.

2016. In: Gross, K.C., C.Y. Wang; M. Saltveit (Eds), The Commercial Storage of Fruits, Vegetables, and Florist and Nursery Stocks. United States Department of Agriculture (USDA) - Agricultural Research Service-Agriculture Handbook, $\mathrm{N}^{\circ} 66.780 \mathrm{p}$.

Ismail, M.A., Chen, H., Baldwin, E.A.; Plotto, A.

2005 Changes in enzyme-assisted peeling efficiency and quality of fresh 'Valencia' orange and of stored 'Valencia' orange and 'Ruby red' grapefruit. Proceedings of the Florida State Horticultural Society, 118: 403-405.

ISO 8586

2012. Sensory analysis: general guide for the selection, training and monitoring of selected assessors and expert sensory assesors.

Jackson, D.I. and Looney N.E.

2003. Producción de frutas de climas templados y subtropicales. Ed. Acribia. Zaragoza, España. 268 p.

Karacay, E.; Ayhan, Z.

2010. Microbial, Physical, Chemical and Sensory Qualities of Minimally Processed and Modified Atmosphere Packaged
"Ready to Eat" Orange Segments. International Journal of Food Properties, 13, 960-971.

Mondino, M.; Ferratto, J.

2006. El análisis sensorial, una herramienta para la evaluación de la calidad desde el consumidor. Agromensajes, 18: 16-23.

Murray J.M, Delahunty C.M.; Baxter I.A

2001. Descriptive sensory analysis: past, present and future. Food Research International, 34(6): 461-471.

Pao S.; Petracek P.D.

1997. Shelf life extension of peeled oranges by citric acid treatment. Food Microbiology, 14: 485-491.

Parzanese, $M$.

2012. Vegetales mínimamente Procesados. Revista Alimentos Argentinos, 55: 30-39.

Pinnavaia, S., Senesi, E., Plotto, A., Narciso, J.A.; Baldwin E.A. 2007. Flavor and Other Quality Factors of Enzyme-peeled Oranges Treated with Citric Acid. HortScience, 42(7): 1644-1650.

Plaza, L., Crespo, I., de Pascual-Teresa, S., de Ancos, B., Sánchez-Moreno, C., Marina Muñoz, M.; Cano, M.P.

2011. Impact of minimal processing on orange bioactive compounds during refrigerated storage. Food Chemistry, 124: 646-651.

Porto Cardoso, J.M.; Bolini, H.M.A.

2008. Descriptive profile of peach nectar sweetened with sucrose and different sweeteners. Journal of Sensory Studies, 23: 804-816.

Pretel, M.T., Lozano, P., Riquelme, F.; Romojaro, F.

1997. Pectic enzymes in fresh fruit processing: optimization of enzymic peeling of oranges. Process Biochemistry, 32(1), 43-49.

Pretel, M. T., Botella, M.A., Amor, A., Serrano, M., Isabel

Egea, I.; Romojaro, F.

2007. Obtaining fruit segments from a traditional orange variety (Citrus sinensis (L.) Osbeck cv. Sangrina) by enzymatic peeling. European Food Research and Technology, 225: 783-788.

Pretel, M.T., Sanchez-Bel, P., Egea, I.; Romojaro, F.

2008. Enzymatic peeling of citrus fruits: factors affecting degradation of the albedo. Tree and Forestry Science and Biotechnology 2 (Special Issue 1): 52- 59.

Rogers, L.

2017. Method training for sensory panels. In: L. Rogers (Ed.). Sensory Panel Management: A Practical Handbook for Recruitment, Training and Performance. Woodhead Publishing. (Part Two, Chapter 7). DOI: 10.1016/ B978-0-08-101001-3.00007-0.

Xiang, Z., Chen, X., Qian, C., He, K.; Xiao, X.

2019. Determination of volatile flavors in fresh navel orange by multidimensional gas chromatography quadrupole time offlight mass spectrometry. Analytical Letters, 1-13. 